\title{
"Modkulturens" nødvendighed
}

\author{
Af Bo Skøtt
}

\begin{abstract}
Med udgangspunkt $i$ et ph.d. projekt på Det Informationsvidenskabelige Akademi (tidligere Danmarks Biblioteksskole) indleder jeg denne artikel med en proesentation af to forskellige synsvinkler på fonomenet "modkultur", der baseres på et sncevert henholdsvis bredt kulturbegreb. Diskussionen mellem disse to opfattelser af "modkultur" knytter jeg an til mit projekts ophav i biblioteks- og informationsvidenskaben, til en definition af kulturbegrebet og til de studier af bevidsthedsformer, jeg har gennemfort. Dette fører frem til en diskussion af selve begrebet "modkulter", begrebets implicitte antagelser, samt eksplicitte konsekvenser. Jeg ploederer undervejs for nødvendigheden af, at anloegge et kulturanalytisk perspektiv, idet folkelige foellesskaber antages at vore alt for komplekse til, at umiddelbare studier af dem kan vore adcekvate. Blandt andet stiller jeg spørgsmålstegn ved, hvorvidt den forklarende beskrivelse som anvendelsen af et sncevert kulturbegreb medfører, kan anvendes $i$ bestrcebelserne på at fortolke og forstå "modkulturel" aktivisme. Artiklen afsluttes med at udbygge relationen og interessefoellesskabet mellem på den ene side de folkelige kulturinstitutioners aktivisme og folkebibliotekernes kulturformidling på den anden og med at argumen-
\end{abstract}

Bo Skøtt er cand. mag, ph.d. studerende og tidligere ansat ved Det Informationsvidenskabelige Akademi $i$ Aalborg.Skott.666@gmail.com tere for anvendelsen af betegnelsen "sociokulturelle fallesskaber" i stedet for "modkulturer" om folkelige fallesskaber.

\section{Indledning}

Lørdag d. 28. april 2007 var temaet "Modkultur" til debat på Danmarks Radios program 1. Med undertitlen "Hvorfor er det så svært at være imod?" (Agenda d. 28.4.2007) diskuterede forskellige notabiliteter indenfor universitets-, kultur- og bladverdenen "modkulturens" popularisering.

To synspunkter gjorde sig i ovennævnte temaudsendelse gældende. På den ene side definerede antropologen Dennis Nørmark ud fra et mere traditionelt kulturkonservativt kulturbegreb, "modkulturer" som værende i besiddelse af en række revolutionsromantiske forestillinger om at tilhøre en lille udvalgt skare, der har fundet sandheden. "Modkultur" blev, med udgangspunkt i Joseph Heath og Andrew Potters publikation "Rebel - modkultur som globalt brand" (2004) beskrevet som en falsk bevidsthed, betegnende visse sociokulturelle fællesskabers opposition til den almene befolkning og med den, en irrationel følelse af at kunne sætte sig ud over "systemet". Disse fællesskabers eksistentielle vilkår, var Nørmarks argumentation, består af et fælles veto - en følt modstand mod givne fænomener i samfundet (for eksempel forbrugerisme, kommercialisering, globalisering, rovdrift på naturen, etc.), - men tynges samtidig af et todelt paradoks: dels "modkulturens" lidenhed og følelsen af eksklusivitet, der ophører i det øjeblik be- 
folkningen viser sig lydhørig og ideologien ophøjes til mainstream, dels "modkulturens" aktivisme som fremmende i stedet for hæmmende forbrugerisme. Et illustrativt eksempel i udsendelsen var økologi. Det er en bevægelse, hvis udvikling gennem de seneste årtier er gået fra at være en ideologisk tumleplads for økofreaks og sundhedsfanatikere til en i den grad seriøs medspiller i både landbrugets produktion af råvarer og i detailhandlens markedsføringsstrategier. Ifølge Nørmark er økologi imidlertid ikke længere interessant som modkulturel markering på grund af sin konvertering fra eksklusiv markør til mainstream forbrug. Dertil kommer at slaget om økologien viser, hvordan markedet virker: ikke gennem indoptagelse, men via tilpasning til forskellige subjekter og gruppers behov for både identifikation og distinktion. Netop behovet for distinktion fremmer ifølge Potter og Heath forbrugerisme.

Interessant nok kunne fortalerne for det modsatte synspunkt Jørgen Ramskov, direktør for Nimbus Film og Chris Petersen, moderedaktør på Eurowoman, benytte nøjagtig samme eksempelmateriale, $ø$ kologien, til at understøtte deres, diametralt modsatte konklusioner. Ud fra en mere positiv imødekommenhed, betragter Ramskov og Petersen "modkulturer" som kreative og innovative fællesskabers opgør med vanetænkning. Alternativers implementering i mainstream tænkning blev i deres perspektiv ikke set som et knæfald for markedskræfterne, men som en succesfuld intervention. Med ovennævnte eksempel in mente, er økologi en succes, fordi det udtrykkeligt viser "modkulturens" mulighed for at skabe samfundsmæssige ændringer gennem praksis. Den økologiske "modkulturs" arbejde har således vist sig at være både bære- og konkurrencedygtig på de almindelige markedsmæssige betingelser. "Modkulturens" forvandling fra sociokulturelt fællesskab til mainstream udgør således ikke fra denne synsvinkel et problem, men illustrerer derimod "modkulturernes" virkelige styrke og gennemslagskraft.

\section{Analytiske fikspunkter}

Jeg vil i det efterfølgende forfølge ovennævnte diskussion om "modkulturernes" karakteristika og berettigelse, og relatere den til et større forskningsprojekt, jeg afsluttede i august 2010. Med baggrund i biblioteks- og informationsvidenskaben har jeg i projektet "By Any Beat Necessary" arbejdet med en "modkultur" som case: kultur- og aktivitetshu- set 1000 fryd i Aalborg. Det, der især har interesseret mig i forbindelse med mine studier er, hvordan aktivisterne forhandler mening offentligt og i fællesskab, hvordan de håndterer senmoderne, kognitive erfaringer og kropslige oplevelser, samt hvordan de organiserer folkelig viden indbyrdes. Disse tre fænomener har jeg studeret gennem feltobservationer, aktiv deltagelse i møder og arrangementer, samt gennem analyser af en række medlemmernes individuelle fortællinger - og netop heri ligger det interessante, set ud fra et biblioteks- og informationsvidenskabeligt perspektiv. De danske folkebiblioteker har i mange år - og gør det for så vidt stadig - arbejdet ud fra et forholdsvist snævert kulturbegreb, hvor det især har været de mere traditionelle kunstformer - teater, musik, billedkunst og selvfølgelige fag- og skønlitteratur, der har været udgangspunktet for deres formidlingsaktiviteter. Men folkebibliotekerne har også i en længere årrække arbejdet ihærdigt på at blive civile arenaer for herredømmefri kommunikation og mellemmenneskelig interaktion - og dermed udvidde sit kulturbegreb. Det er denne sidste opfattelse af folkebiblioteksrummet som en arena for folkelig ${ }^{1}$ aktivisme, jeg har forsøgt at udfordre i mit studie. Det, jeg blandt andet har interesseret mig for, har været hvilke myter og ritualer, der er aktive i et "modkulturelt" fællesskab - ikke som de kommer til udtryk i en kulturpolitik, samfundsmæssig diskussion for eller imod, men som de fortællinger og praksisser, der finder sted indenfor en lokal, "modkulturel" konstellation. Denne artikel kan i sagens natur ikke blive en uddybende gennemgang af samtlige analytiske fikspunkter, men vil være et forsøg på at indplacere mit projekt i den verserende, offentlige diskussion af "modkultur" ud fra hvilke fortællinger, der er på spil - og på at nuancere denne debat. Jeg vil i den forbindelse plædere for et mindre polariseret syn på "modkultur" og i stedet argumentere for en karakteristik af "modkulturer" som folkelige formationer af sociokulturel karakter, hvor også medkulturelle elementer spiller en aktiv rolle.

\section{Om at være imod}

En "modkulturs" styrke består i at initiere ændringer i den herskende fremstilling af samfundet. Den herskende fremstilling af samfundet udgår ikke længere ud fra centralt administrativt, økonomisk eller kulturelt hold, men betegner, i senmoderne samfund, den politiske og økonomiske konsensus om hvilken, der kan samles tilstrækkeligt hegemonisk magt. 
Dette samfundsmæssige vilkår arbejder Ann Swidler videre med i sine studier af "modkulturer" i artiklen "Cultural Movements and Social Power" (1995). Her beskriver hun, hvordan kulturelle og sociale bevægelser, gennem især tre forskellige elementer, publicity, praksis og magt, har mulighed for initiere samfundsmæssige forandringer. Gennem udlevelse af alternative livsstile, er aktivister og medlemmer af forskellige grupperinger med til at producere og reproducere det "modkulturelle" fællesskab, gennem "... public symbols displayed a system of meaning, what some would call a semiotic code, rather than ideas that were in any person's head." - og dermed i stand til at intervenere i den herskende, hegemoniske opfattelse af samfundet (Swidler, 1995, s. 27).

"Modkulturernes" stærkeste middel til at fremkalde forandringer knytter sig til deres evne til at ændre på kulturelt, givne koder. En sådan transformering indeholder både aspekter af publicity, praksis og af magt: "Even without conscious efforts at publicity, one of the most important effects social movements have is publicity enacting images that confound existing cultural coding. From the punk subculture's deliberate embrace of "ugly" styles (meant to muddle standard status coding (...) to the Black Panters' display of militant, disciplined, armed black revolutionaries to the New Left spectacle of middle-class collage students being beaten by police (...), altering culture codings is one of the most powerful ways social movements actually bring about changes." (Swidler, 1995, s. 27 - min kursivering). Det er altså gennem eksemplets magt, den offentlige stillen sig selv og sine alternative fortællinger og praksis til skue, at visse "modkulturer" formår at initiere forandringer som det eksempelvis er sket med økologi.

\section{Problemfelt}

Hermed har jeg også, omend implicit, introduceret, hvad jeg betragter som kerneproblemet i både Ramskov, Petersen og (især) Nørmarks etiketteringer af "modkultur" som sociale, politiske og kulturelle fænomener: den retorisk determinerede eksponering af det, "modkulturerne" er imod! At behæfte et folkeligt fællesskabs engagement og bestræbelser på at ændrer samfundsmæssige forhold med prædikatet "modkultur" har en række implikationer, som jeg i det efterfølgende vil diskutere og kommentere. Min antagelse er, at kulturpolitiske artikulationer af fællesskaber som "modkultur" rummer en kulturel for-opfattelse, der potentielt siger mere om beteg- nerens ophav, hvilke i nærværende sammenhæng sige forskeren, debattøren og journalistens opfattelser, fordomme og tolkninger end om de betegnede ("modkulturerne"). Men det er også min antagelse at sådanne artikulationer har indflydelse på, hvilke fortællinger og hvilken praksis, aktivisterne faktisk kan initiere. Fortællinger og praksis er på godt og ondt udtryk for "semiotiske koder" (jævnfør Swidler ovenfor), der skal give involverede mennesker mening i en given samfundsmæssig kontekst. Og finder mennesker ikke dem i den herskende fremstilling af samfundet, søger de alternativer.

\section{Kulturbegrebet}

Disse to antagelser bygger på, at jeg betragter kultur ud fra et kulturanalytisk kulturbegreb, som både et særligt område for individuel erfaringsdannelse og som værende under indflydelse af generelle, samfundsmæssige forhold. Den kulturanalytiske skoledannelse jeg refererer til, har sit udspring i en særlig skandinavisk tradition, der igen har sin oprindelse i forskningen på $\mathrm{CCCS}^{2}$ og hvis kulturbegreb er en syntese af to traditionelle kulturbegreber: på den ene side et traditionelt borgerligt kultursyn, hvor geniers unikke, kunstneriske artefakter skabes af de få for de mange som kondenserede udtryk for et samfunds værdier og normer. Derfor kommer tilegnelsen af disse, gennem historien, til at udtrykke den enkeltes individuelle, intellektuelle og finkulturelle dannelse (jævnfør Fjord Jensen, 1988). Og på den anden side et lige så traditionelt marxistisk kultursyn, der argumenterer for, at frembringelsen af kunstneriske produkter i det borgerlige samfund er betinget af normative strukturelle, samfundsmæssige og materiale forhold i samfundet, hvorfor kravet om dannelse gennem finkulturelle artefakter ses som resultatet af ideologiske fejlslutninger. Kunsten skal derimod være revolutionær, afslørende i forhold til dette samfunds dekadence og om muligt foregribe de socialistiske idealers virkeliggørelse.

Forskningen på CCCS udvikler i 1960'erne og 70 'erne et nyt kulturbegreb, der opfatter kulturen som både et særligt område for individuel erfaringsdannelse, samtidig med at samfundets ydre, hegemoniske vilkår anerkendes som influerende på denne erfaringsdannelse (Bay og Drotner, 1986, s. 17 - 19). Dette kulturbegreb er videreført i den skandinaviske kulturanalyse. 
Det sncevre kulturbegreb

Til denne forståelse af kultur som livsmåder henter jeg yderligere inspiration hos Johan Fjord Jensen (Fjord Jensen, 1988, s.155ff.). Fjord Jensen skelner mellem to relationelle kulturbegreber: et snævert og et bredt kulturbegreb. Det snævre kulturbegreb henviser til et givent samfunds kunstneriske produktion. Denne produktion er naturligvis betinget af de kulturelle og sociale (og økonomiske, politiske, etc.) vilkår, som mennesker er underlagt i givne samfund. Betegnelsen knytter an til de kunstneriske frembringelser, "artefakterne", som den materielle del af kulturen, vi kan have eller tilegne os og ved hvis tilegnelse, vi som mennesker dannes. Det er især gennem iagttagelse af det snævre kulturbegreb, at kultur(formidlings) institutioner som folkebibliotekerne har bedrevet deres virksomhed. Gennem formidling af et givent samfunds hævdvundne kunstneriske artefakter - især fag- og skønlitteratur - har folkebibliotekerne som offentlige institutioner (haft) mulighed for at influere på menneskers levemåder direkte og indenfor en hævdvunden, samfundsmæssig standart.

\section{Det brede kulturbegreb}

Det brede kulturbegreb definerer Fjord Jensen som omfattende de handlinger i praksis, mennesker udfører forholdsvist ubevidst, ureflekteret og rutinemæssigt i deres hverdag - en modus vivendi. Det brede kulturbegreb betegner, med andre ord, den kultur vi lever eller er og det, der traditionelt har udgjort genstandsfeltet for kultur(formidlings) institutionernes dannelsesmæssige bestræbelser.

Pointen hos Fjord Jensen er, at begge kulturbegreber er nødvendige for den fulde forståelse af samfundets sociale og kulturelle konstellation, men at vi kun kan iagttage det brede henholdsvis det snævre kulturbegreb gennem en analytisk skelnen og hver for sig: "Har og er, forholder sig [...] komplementært til hinanden. De forudsætter hinanden. Men de udelukker også hinanden, kan ikke begribes i samme moment uden at deres egenart hver for sig går til grunde." (Jensen, 1988, s. 159 - 160). Fjord Jensen formulerer dette meget elegant med et billede fra psykologien, Rubens figurer: vi ser enten vasen eller de to ansigter - ikke begge dele på én gang.

\section{Hvad er "modkulturer"?}

Kunstneriske frembringelser opstår derfor aldrig i kulturelle, sociale eller værdimæssige vakuum, men må nødvendigvis knytte an til samfundsmæssige konstellationer - lige såvel som en hvilken som helst samfundsmæssig konstellation altid vil producere kulturelle og kunstneriske artefakter (Fjord Jensen, 1988). Denne iagttagelse har naturligvis konsekvenser for, hvordan folkebibliotekerne kan betragte deres virksomhed. Folkebibliotekernes raison d'etre er netop bygget op omkring deres muligheder for at bibringe mennesker evnen til at lede sig selv ved hjælp af deres egen, sunde fornuft - og denne evne er især blevet forsøgt initieret via nationalstatens "store" fortælling om sig selv (eller reminiscenserne heraf): det danske (kulturen), det demokratiske (parlamentarisme) og det historiske (arv og oprindelse). Som nævnt ovenfor er påvirkning af menneskers sociale praksis på folkebibliotekerne sket gennem formidling af kunstneriske og kulturelle artefakter, primært skøn- og faglitteratur.

Men hvad med "modkulturernes" modus vivendi? Ud fra Bay \& Drotner og Fjord Jensens definitioner vil jeg betegne folkelige fællesskabers "modkulturelle" handlinger i praksis og deres fortællinger som udtryk for alternative livsmåder i forhold til den herskende fremstilling af samfundet, der er givet i nationens "store" fortælling om sig selv. Problemet er, at visse folkelige formationer i dag, har en så afvigende karakter, at afvigelsen i sig selv, for udenforstående, legitimerer betegnelsen af disse som "modkultur". For tiden er det især mere radikale, politiske og kulturelle fællesskaber på venstrefløjen (som Ungdomshuset, Christiania - og 1000fryd), der refereres til med betegnelsen "modkultur" som negativ prædikat og det er denne, hvad jeg opfatter som, tendentielle artikulation af visse folkelige fællesskaber, jeg her vil argumentere imod: "modkulturel" er ikke noget aktivisterne er, men noget de gør - og især bliver gjort til!

\section{Om at vere imod}

Spørgsmålet er, om fællesskaber kan bygges op omkring livsmåder, der udelukkende går imod og på horisonter, hvis rækkevidde ikke når længere end til systemets/normativitetens fald? Nej netop! - siger Nørmark, og derfor må disse fællesskaber kontinuerlig være i proces: dels på vej væk fra gamle mærkesager, dels på jagt efter nye, hvor modstand kan ud- 
foldes og det eksklusive sammenhold reproduceres. Men i virkeligheden batter det ikke noget, for der er ikke noget system at gøre oprør mod. Med henvisning til Potter og Heaths skriver Nørmark andetsteds: "Bogen er en suveræn analyse af én af de mest genstridige myter i vestlig kultur. Og genstridig er den, fordi den som alle andre konspirationsmyter anvender enhver kritik som en bekræftelse af sin egen rigtighed: Benægtelsen af illusionen viser blot, hvor magtfuld den er! Det stærke ved Potter og Heaths bog er, at den netop ikke handler om, hvordan modkulturen bliver sit eget brand og dermed understøtter systemet. Den hævder, at systemet ganske enkelt ikke eksisterer. Systemet er nemlig os alle sammen. Der er ingen undertrykkelse, der er bare mennesker, der render rundt og handler $i$ verden. Der er ingen virkelighed bag virkeligheden, der er blot det, vi ser." (Nørmark, 2007 - min kursivering).

Umiddelbart virker Nørmarks anskuelser plausible om end en anelse endimensionelle. Jeg tolker den modvilje som han udtrykker overfor "modkulturerne" som udtryk for en kulturpolitisk holdning, baseret på et forholdsvist snævert kulturbegreb, hvor samfundets strukturelle og materielle vilkår, jævnfør Bay \& Drotner, ikke levnes nogen indflydelse. Det må formodes at være udgangspunktet, idet der ikke kan være nogen virkelighed bag "virkeligheden" og intet system bag "systemet", kun mennesker, der interagerer. Men spørgsmålet er, om Nørmarks strategi er en farbar vej til en nærme analyse og tolkning af de folkelige fællesskaber, der er i fokus?

For det første: kan vi med god videnskabelig samvittighed antage, at vi i arbejdet med folkelige fællesskaber, med fortællinger og med handlinger i praksis, udelukkende kan anerkende umiddelbar empiri som eneste tilgang til genstandsfeltet? Og kan vi igennem studier baseret på et sådan perspektiv, forvente at efterspore og finde forklaringer af nomotetisk værdi? Ved at operere med forskellige erkendelsesniveauer formår Swidler (1995) for eksempel at nærme sig en indsigt $i$, hvilke strukturelle og konstruktivistiske fænomener, der udgør essentielle bevæggrunde for de "social movements", hun studerer (former for publicity, praksis og magt). Hvordan disse egenskaber kommer til udtryk i konkrete, samfundsmæssige kontekster igennem "modkulturernes" praksis, er en anden sag. Det hidrører så at sige til et "niveau under" Swidlers argumentation. Pointen er, at ved at operere med både umiddelbare iagttagelser og middelbar tolkninger af symbolik, diskurs, m.v. opnår hun nye erkendelser af, nye indsigter i og ny forståelse for aktivisternes motivation og bevæggrund.

Det er imidlertid netop her, på "niveauet under" at Nørmarks argumentation udfolder sig: gennem observationer af en umiddelbar empiri, hævder han en mulighed for at udsige noget essentielt og universelt forklarende om "modkulturers" motivation og bevæggrunde. Konklusionen på Nørmarks studier af hans empiri, de folkelige fællesskaber på Nørrebro og deres aktivisme, er en umiddelbar tolkning af disse som reaktionære og oprørsromantiske. Dette er der flere problemer i:

- Hjælper en sådan umiddelbar artikulation af "modkulturer" som reaktionære og oprørsromantiske os med at forstå disse fællesskaber og deres (irrationelle) komplekse bevæggrunde ${ }^{3}$ - og dermed deres aktivisme, så vi kan forholde os hensigtsmæssigt til dem - eller er ærindet en kulturpolitisk afskrivning af dem?

- Kan vi tillade os at anvende et snævert kulturbegreb i bestræbelserne på at studere så komplekse fænomener som socialitet, kulturalitet og sociokulturelle fællesskabers samfundsmæssigheder og tillige på basis ét studiet af én "modkultur" forvente udbytte af nomotetisk karakter?

- Og hjælper anvendelsen af et snævert kulturbegreb os med at forstå andre "modkulturelle", folkelige fænomener som hooliganisme, rockermiljøer, politiske, religiøse eller videnskabelige fundamentalister - eller blot noget så hverdagsagtigt som sort arbejde, grafitti eller anden kriminalitet? Har de samme "oprørsromantiske", "metafysiske" karakteristika som de venstreorienterede?

Man kan med rette diskutere om alle de fænomener, jeg nævner i sidste punkt har en struktur, der gør, at vi med god ret kan tale om dem som fællesskaber (udgør folk, der arbejder sort en gruppe/et fællesskab?), men pointen er, at de alle udgør forskellige former for folkelige modstand. De repræsenterer alle (om end med varierende kulturelle, sociale og/eller politisk ophav) oprør imod den herskende fremstilling af samfundet og dets sociale, økonomiske, administrative, bureaukratiske, kulturelle, etc. systemer. De anvender alle i varierende grad forskellige former for publicity (eller mangel på samme), 
praksis og lokal magt $\mathrm{i}$ bestræbelserne på at ændre ved den hegemoniske konsensus, der for tiden tegner Danmarks som senmoderne samfund. Og de er alle, for udenforstående, umiddelbart lige så uforståelige som aktivismen på Ungdomshuset, Christiania eller på 1000fryd. De bliver imidlertid forståelige på et symbolsk niveau og det er her Nørmark med flere for mig at se begår den største fejl: at afskrive eksistensen af det, der ikke kan iagttages på det umiddelbare plan. Det er netop på det symbolske og diskursive niveau, at socialitet og kulturalitet for alvor for betydning, som meningsgivende strukturer (se også Geertz, u.å.).

Problemet med den position, der i den indledende diskussion fremføres af Nørmark, er, ud fra en skandinavisk, kulturanalytisk position, således ikke at den fremføres: der er alle mulige gode grunde til at betragte et genstandsfelt fra mange forskellige synsvinkler, herunder en umiddelbar iagttagerposition. Det der er problemet, er Nørmarks absolutistiske udlægning af sine resultater, af sin teoretiske baggrund og påstanden om, at erkendelse udelukkende sker som en induktiv proces. Populært sagt: hvis ikke empiri lader sig sanse, eksisterer den ikke! Det beskæmmende ved Nørmarks retorik er, at det stiller umulige betingelser op for en videre diskussion mellem forskellige videnskabelige positioner og validitet af at have forskellige synsvinkler på genstandsfeltet. Derfor betragter jeg hans bidrag til debatten mere som et værdi- eller kulturpolitisk partsindlæg i en løbende, offentlig forhandling om hegemonisk fremstilling af samfundet, end et egentligt videnskabeligt bidrag til forskning i folkelige fællesskaber.

\section{Pro et contra}

For det andet: kan man tillade sig at antage at det, der for en udenforstående ser ud som en "modkulturs" kontrasive aktivisme nødvendigvis betyder at aktivisterne blot og bart er imod? Eller formuleret på en lidt anden vis: er der ikke noget "modkulturerne" er for? I det indledende eksempel er det netop dette for Ramskov og Petersen pointerer: den økologiske tanke som "modkultur" er således for at lade tvivlen om eventuelle pesticidernes skadevoldende virkninger komme forbrugeren til gode, for at skabe bæredygtighed i landbruget og dermed for minimere rovdrift og i sidste instans dennes indvirkning på klimaforandringer - eller i forhold til mit projekt, kulturstudiet af 1000fryd: for en afsystematisering af livsverden, for reduktion af de negative konsekven- ser af forbrugerisme, kommercialisering, globalisering, etc. "Modkulturens" for er i mit projekt lig fællesskabet forsøg på at lade deres "små", lokale fortællinger om sig selv, om hinanden og om samfundet komme til udtryk gennem aktivismens rituelle, kunstneriske udtryk. Disse fortællinger antager på 1000fryd helt konkret form af debat om forholdet til andre folkelige fællesskaber (især AaB'erne), til myndigheder, journalister, politiet, etc., karakteren af folkekøkkenet (vegetarisk versus vegansk), kønspolitiske diskussioner, kultur versus politisk profil og rygepolitik. Der er således tale om tematikker, der er gode at tænke med i aktivisternes modstand mod det konventionelle og hyldest af det alternative, fordi de kan udleves i praksis som "modus vivendi". ${ }^{4}$ Disse fortællinger udtrykker samtidig en folkelig aktivisme, der er umulig at favne gennem etablerede kultur(formidlings)institutioner, herunder i folkebibliotekerne, fordi væsentlige aspekter i disse tematikker er den informelle, semi-strukturelle organisering hvori det enkelte menneske har stor, direkte indflydelse, den nærdemokratiske, folkelige forhandling og en mere restriktiv, kollektiv forpligtigelse, som aktivisterne finder i fællesskabets dynamiske karakter på 1000 fryd. ${ }^{5}$ En af kulturanalysens styrker er, at den tillader mikrosociologisk fokusering på fortællinger om det, folkelige fællesskaber er imod og for som udtryk for levet liv. Der er således ingen moralske, etiske eller filosofiske afvisninger af forskellige livsmåder, men derimod en anerkendelse af fortællinger og tilhørende praksis som meningsgivende for de involverede mennesker og dermed "principielt begribelige" som kulturelle og sociale fænomener (Hastrup, 2004, s. 15 - 16).

Selvom Ramskov og Petersen således $i$ udgangspunktet er positive overfor de kreative og innovative aspekter af sociokulturelle fællesskabers aktivisme, vil jeg alligevel argumentere for, at også de bærer ved til "modkulturernes" stigmatiserende marginalisering i den offentlige debat. Det gør de ved at bibeholde og annamme betegnelsen "modkultur". Derved fortsætter de med diskursivt at artikulere en grundlæggende karakteristik af disse fællesskaber som værende imod. Jeg betragter i modsætning hertil betegnelsen "modkultur" som en etikettering, visse fællesskaber har fået af visse kulturpolitikere og kulturpolitiske aktører, og som nu har vundet hævd i offentligheden som måden at betegne disse folkelige fællesskaber på. Ovennævnte bevirker at begrebet "modkultur" og den kontekst hvori begrebet anven- 
des, bærer på en bias, der er normativ i sin konsekvens: det, de såkaldte "modkulturer" er imod må nødvendigvis være det af politikere, aktører, medier - og befolkningen - alment accepterede og ubevidste eller ikke-reflekterede værdisæt i samfundet, det være sig ideologi, samfundsmæssig form, organisering, politik eller lignende. At aktivisternes engagement bygger på en subjektiv utilfredshed med tingenes tilstand og et ønske om forandringer i fællesskab er uomtvistelig, men vilkårene for dette forbliver skjult i den aktuelle betegnelse af fællesskaberne som "modkulturelle".

\section{Symbolsk kompleksitet}

For det tredje: er betegnelsen "modkultur" befordrende eller slørende i forhold til udenforståendes erkendelse af alternative fællesskabers sociale kompleksitet? Prædikatet "modkultur", vil jeg jævnfør min henvisning til Nørmark ovenfor hævde, er udtryk for et værdi- eller kulturpolitisk synspunkts postulat. "Modkulturens" oppositionelle træk bliver i sig selv betegnende, fordi forskellene er umiddelbare iagttagelige og markante: den outrerede tøjstil, kropsudsmykning og handlingsmæssige kodekser, demonstrationernes kakofoniske tendenser og gadekampe. Men et udgangspunkt i et snævert kulturbegreb kan kun konstatere at det forholder sig sådan, ikke hvorfor. Den kan ikke, i modsætning til kulturanalysen, forklare at "modkulturers" handlinger i praksis, er en mere end kærkommen lejlighed i op til flere forskellige symbolske relationer. I modsætning til Nørmarks umiddelbare iagttagelse og subjektive indignation over de store omkostninger ved forskellige konflikters eskalering (det billigste havde nok været at lade Ungdomshuset blive, hvor det var!), eller "modkulturernes" manglende respekt for demokratiet, for øvrigheden og for samfundet, spiller den type publicity også en vigtig rolle som udtryk for lovgivende og udøvende myndigheds raison d'etre:

- Håndtering af "modkulturer" illustrerer politikernes og myndighedernes demokratiske tolerance - så længe "modkulturerne" vel at mærke (op)holder sig inden for de skrevne og (især) uskrevne regler for dette samfund. Derfor eksisterer fænomener som 1000 fryd og Christiania stadig.

- Håndtering af "modkulturer" illustrerer hvad der sker, når disse rammer overskrides og myndighederne tager fat. Den udøvende magts fremfærd er ikke tilfældig: graden af magtanvendelse, der er nødvendig for at gennemføre trufne beslutninger vil blive anvendt - og det vises symbolsk, såvel som faktisk. Derfor "flyttes" Ungdomshuset!

- Håndtering af "modkulturer" er et illustrativt eksempel i forhold til andre sociokulturelle grupperinger, der kunne tænkes at ville forsøge sig med noget tilsvarende: se konsekvenserne!

Konflikt er, jævnfør Swidler ovenfor, en væsentlig del af folkelige fællesskabers kommunikation, hvad enten de antager form af fællesskabers afvigelser i forhold til samfundets "store" historie eller udtrykker individuel modstand i "modkulturens" "små" fortællinger. Begrebet "modkultur" er således et tilsyneladende objektivt og klart defineret begreb, men kan, ud fra en kulturanalytisk tilgang, tolkes som et både subjektivt og biased prædikat, der hæftes på de, fra den hævdvundne norm, afvigende fællesskaber med kategoriseringens klassiske problematik bibeholdt: en endimensional eksponering af en eller få forhold ved en kompleks, social struktur, hvilket resulterer i stigmatiserende effekter. Jeg vil derfor supplerende ovennævnte postulater af "modkulturernes" karakteristika med følgende:

- I hvert fald fællesskabet omkring 1000 fryd indskriver sig selv i samfundet gennem betegnelser som "alternativ spillested", "brugerstyret kulturhus" eller "den alternative scene i Aalborg og har gjort det i 25 år.

- Fællesskabet indskriver sig i den "modkulturelle" artikulation idet 1000 fryd falder ind under rammerne af en række implicitte antagelser om "modkulturelle" strømninger; opposition til det bestående, orientering mod den politiske venstrefløj, skæve vinkler på levet liv, aktivisme på gadeniveau og DIY - konceptet ${ }^{6}$. Den alternative, uafhængige (indie) musik, der i overvejende grad fremføres og distribueres på et ikke-kommercielt grundlag spiller en markant rolle i miljøet, tillige med den fra prosaisk til outrerede uniformering, den veganiske gastronomi - eller økologi, der i modsætning til Nørmarks postulat ikke er forladt på 1000 fryd til trods for dens mainstream popularitet.

- For aktivisterne på kulturhuset gælder også at "modkultur" som begreb ikke synes tilstrækkeligt 
betegnende for hverken stedets eller aktivisternes egen forståelse. Der er aktivister, der definerer sig som rebeller, "ræverøde", politiske venstrefløjsaktivister, punkere, anarkister, kommunister - eller blot og bart 1000fryder. 1000fryd defineres som undergrundsscene, et alternativ til de etablerede spillesteder, som aktivitetshus, som brugerstyret kulturhus, som cafe og værested, etc. mens begrebet "modkultur" kun lejlighedsvist anvendes som betegnelse - og når det sker, er det som regel proaktivt som modpol til, hvad aktivisterne opfatter som negative konsekvenser af senmodernitet og samfundsadministrationens systemlogik. Aktivisterne er alt for skabende, alt for meningsdannelse og identitetskonstruerende til at kunne betegnes - og betegne sig - som blot og bart imod.

De omtalte "modkulturers" ideologiske mærkesager er af en sådan beskaffenhed, at de skaber grundlag for offentlige meningsforhandlinger og aktivisternes håndtering af erfaringer og oplevelser. De giver aktivisterne en social og kulturel legitimitet, hvor logisk irrationelle deres mærkesager end måtte fremstår for andre, udenforstående.

\section{Biblioteksfaglige implikationer?}

Med udgangspunkt i ovennævnte, kan jeg nu skitsere de foreløbige antagelser om mulige koblinger mellem folkebibliotekernes kulturformidlende praksis og de folkelige "modkulturers" ditto.

Ud fra her anlagte perspektiv vil jeg argumentere for, at folkebibliotekernes virksomhed kan betragtes som en bestræbelse på at fortælle både "store" historier om det danske, det demokratiske og det historiske, og mere lokalt funderede, "små" fortællinger om nærområdernes kulturelle og sociale særpræg. Det vil med andre ord sige at folkebibliotekerne forsøger at agere i et spændingsfelt mellem forpligtigelser overfor samfundets kollektive sammenhængskraft og hensyn til menneskers individuelle autonomi. Den første forpligtigelse kommer (stadig) til udtryk gennem formidling af kunstneriske og kulturelle artefakter, især fag- og skønlitteratur, men også gennem musik, udstillinger, debataftner, etc. Derfor indskriver folkebibliotekerne sig i Fjord Jensens snævre kulturbegreb, hvor folkelige fællesskaber udgør baggrund for de kunstneriske og kulturelle artefakter og deres formidlings berettigelse: den ideologiske basis for folkebibliotekerne, hvor fortærsket den end måtte forekomme, er stadig at fungere som grundlaget under individets evne til at lede sig selv ved hjælp af sin egen, sunde fornuft til samfundets gavn og glæde. Hensynet til menneskets individuelle autonomi kommer til udtryk gennem folkebibliotekernes bestræbelser på at stille civile arenaer til rådighed for menneskers frie meningsdannelse og sociale interaktion.

Herved kobler folkebibliotekerne intentionelt det snævre kulturbegreb med det brede, idet folkebiblioteket som en civil arena kommer i stand som offentlig institution med en virksomhed, der bygger på systemlogiske rationaler. Der er med andre ord indbygget et kulturpolitisk paradoks i folkebibliotekerne hvad angår deres (folkebibliotekernes) dannelsesmæssige potentialer. Spørgsmålet er, om ikke en mere kulturanalytisk tilgang med fordel kunne implementeres for at styrke forskningen på dette område?!

I analyseafsnittet ovenfor skitserer jeg tre problemområder, som jeg argumenterer for, alle er aktive i artikulationen af visse folkelige fællesskaber som "modkulturelle". Det drejer sig om 1) det snævre kulturbegrebs muligheder og begrænsninger som udgangspunkt for en forklaringsmodel for komplekse, sociale og kulturelle fænomener som folkelige fællesskaber, 2) om ikke "modkulturer" ikke også altid er medkulturer, hvilket vil sige også altid har noget, de kæmper for og 3) om etiketteringen af visse folkelige fællesskaber som "modkulturelle" er befordrende eller hindrende for en dybere forståelse af deres konstitution, herunder hvordan en sådan etikettering eller artikulation påvirker medlemmerne af de fællesskaber, der refereres til som "modkulturelle". Disse tre spørgsmål vil jeg afslutningsvist sætte ind $i$ en biblioteks- og informationsvidenskabelige, samt faglig kontekst.

\section{Flerfaglighed}

Ad 1) Med tanke på at en overvejende del af biblioteks- og informationsvidenskabelige studier af borgeres adfærd, holdninger og handlinger iværksættes ud fra statistiske metoder, vil jeg her stille spørgsmål ved, hvilken betydning det har. Betyder den aktuelle biblioteks- og informationsvidenskabelige position at disse studier lider af lignende problemer, som jeg kan observere hos Nørmark og den måde han argumenterer på i forhold til "modkulturerne"? Spørgsmålet udspringer af en todelt iagttagelse. For det første kan det biblioteks- og informationsvidenskabelige 
felt i Danmark betegnes som et flervidenskabeligt felt, hvori forskellige videnskabelige traditioner fra især naturvidenskaberne anvendes side om side med sociologiske og humanistiske traditioner. De forskellige videnskabelige traditioner har hver deres fortalere, der hver især fastholder og dyrker traditionernes respektive fagligheder. Men udover at markere det biblioteks- og informationsvidenskabelige felt som forankret i flere forskellige teoretiske traditioner, finder der kun en begrænset udveksling sted, mellem de forskellige fagområder. Tværtimod eksisterer der, trods fagområdets lidenhed, faglige kampe og strid for at fastholde forskellige videnskabsteoretiske rettigheder, paradigmatiske profiler og diskursive tematikker. Denne struktur betyder, at forskningsmæssige resultater tendentielt lines op parataktisk, hvilket vil sige ved siden af hinanden.

\section{Adfcerd}

For det andet eksisterer der en tendens til at studere biblioteksfaglige problemstillinger omkring anvendelse af services, faciliteter og målgrupper etc. i termer af "adfærd". Ud fra en kulturanalytisk betragtning vil jeg argumentere for, at betegnelsen "adfærd" i høj grad relaterer sig til umiddelbare iagttagelser af, hvordan borgerne i praksis agerer i folkebiblioteket, hvor målet er at forklare hvorfor borgerne gør som de gør. Formålet med denne art studier er at optimere borgernes anvendelse af materialesamling, Internet, faciliteter, etc. Naturvidenskabelige metoders primat og fokus på "adfærd" skjuler imidlertid enhver form for intentionalitet, motivation, ønsker, begær, bevæggrund, med mere, fra borgerens side i disse studier - og hvad værre er: disse individuelle foranledninger, intentionalitet, motivation, ønsker, begær, bevæggrund etc. er yderst vanskelige at studere ud fra umiddelbare iagttagelser.

\section{Målgruppestudier}

Ad 2) Et andet spørgsmål, der ligger i forlængelse af ovenstående er, hvilke konsekvenser, folkebibliotekernes interne kategorisering af forskellige "målgrupper" har, for hvordan bibliotekarerne betragter disse grupper. I nærværende forbindelse bliver selve tænkningen i "målgruppekategorier" problematisk. Når bibliotekarer definerer og etiketterer forskellige målgrupper, sker det ud fra en dannelsesmæssig intention om at målrette folkebibliotekets virksomhed mod de mennesker og de grupper, der antageligvis har behov for særlig opmærksomhed. En sådan praksis er i sagens natur problemorienteret, men hvad betyder det, for den videre forståelse af målgrupperne som bibliotekarerne kan, skal og bør have? Hvis jeg overfører den mekanisme som jeg kan iagttage Nørmark anvende i sin definition af visse folkelige fællesskaber som "modkulturelle" og som den nuanceres af Scotson \& Elias, (1994), så vil enhver etikettering være bebyrdet af en række eksponeringer af forskellige forhold, der betragtes som særligt karakteristiske for målgruppen og af en tilsvarende negligering af alle andre - uagtet at disse negligerede forhold også spiller ind på menneskers intentioner, motivation, ønsker, begær, bevæggrunde, etc. Etikettering vil have en tendens til at fremhæve de eksponerede og skjule de negligerede vilkår ved betegnede grupper af mennesker.

\section{Navngivning}

Ad 3) Et tredje spørgsmål er, hvordan ovennævnte kategoriseringspraksis påvirker de mulige målgruppeinterne meningsforhandlinger, håndtering af erfaringer og oplevelser og handlinger i praksis - og hvordan det påvirker bibliotekarerne. Hvad betyder det for borgere at tilhøre og blive betjent som tilhørende en bestemt målgruppe - og hvad betyder det for mennesker, at denne kategorisering oven i købet er/kan være problemorienteret? Med baggrund i Scotson og Elias vil jeg her problematisere denne praksis - ikke fordi kategoriseringer, jævnfør det her anlagte kulturbegreb -, er alene om at determinere et fællesskabs aktionsradius, men fordi navngivning og især i problemorienterede kategorier, har tendens til at skabe en ramme indenfor hvilken, respektive medlemmer kan agere. Scotson og Elias studerer hvordan forskellige grupper af mennesker, der tilsyneladende er ens for en udenforstående betragter, indeholder stærke distanceringer fra hverandre og hvordan forskellige dominerende grupper forsøger at udgrænse mindre dominerende grupper. I de sociale processer finder de, at etikettering spiller en central rolle: "Give a group a bad name and it is likely to live up to it. [...] How far the shame of outsiders produced by the inescapable stigmatisation of an established group turns into paralysing apathy, how far into aggressive norm and lawless, depends on the overall situation." (Scotson \& Elias, 1994, s. xxviii.). Ikke fordi det enkelte medlem af fællesskabet ikke kan gøre brug af sin egen, sunde fornuft til at lede sig selv og herigennem gøre sig fri af en sådan stigmatisering. Men omgivelsernes holdninger og handlinger øver stor indflydelse på, hvordan medlemmer af betegnede fællesskaber forvalter deres muligheder. 
Derfor er det ikke omkostningsfrit, når for eksempel bibliotekarer opererer med forskellige taksonomier af borgere: det har derimod betydning for, hvordan bibliotekarerne imødekommer medlemmer af givne fællesskaber, deres ønsker og behov - og det har ikke mindst betydning for hvordan det enkelte menneske agere i fællesskabet. Larm, uro og problemer på folkebiblioteket kan således tolkes som udtryk for en offentlig forhandling af mening og dermed hegemonisk magt, der finder sted mellem unge mennesker, for eksempel af anden etnisk oprindelse end dansk og bibliotekarerne. Denne forhandling har ikke kun noget at gøre med disse unge menneskers individuelle moralske habitus ellers deres sociale, kulturelle og materielle vilkår af disse menneskers måder at forholde sig på, men i lige så høj grad med, hvordan institutionen "folkebibliotek" iscenesætter sig selv via folkebibliotekarernes artikulation af egne selvforståelser, forhandling af magtpositioner og konstruktion af identiteter.

\section{Konkluderende bemærkninger}

Med udgangspunkt i en verserende diskussion af fænomenet "modkultur", har jeg verificeret og diskuteret to forskellige kulturbegreber, der hver for sig gør sig gældende i kulturpolitiske markeringer og holdninger henholdsvis for og imod fænomenet "modkultur". Jeg argumenterer for, at en del af problemet er, at den "lille" historie ikke længere indgår i samfundets "store" fortælling med samme kulturelle legitimitet som tidligere og at politisk tolerance overfor det folkelige, det afvigende og det alternative (igen) er afløst af dels en dannelsesmæssig, dels en forholdsvis hårdhændet lov-og-orden retorik. Dét, sammen med en tendens til polariserende, diktonomiske betragtninger, betyder mindre opmærksomhed på de underliggende strukturer, symbolske systematikker og meningskonstruerende effekter af menneskers handlinger i praksis. Derfor vil jeg ud fra en kulturanalytisk strategi argumentere for at en langt større fokus på den lille historie, på fortællingerne og på mikrosociologi som udgangspunkt for studier af kulturalitet og socialitet er nødvendig. Det vil jeg ud fra den betragtning at sociokulturelle fællesskaber som for eksempel brugerstyrede kulturhuse og lignende, faktisk har en rolle at spille i samfundet. De skaber rammerne for en lang række menneskers sociale, kulturelle og demokratiske aktiviteter, hvis samfundsmæssige tilknytning er svagere og derfor opfylder nogle af de samme funktioner som folkebib- liotekerne gennem historien har haft og måske stadig har, men som de tilsyneladende ikke længere formår at udfylde i senmoderne tid - i hvert fald hvad angår visse såkaldte "modkulturelle" fællesskaber.

Ovennævnte case, 1000 fryd, er specifik, men ingenlunde unik. Der eksisterer en underskov af sociokulturelle fællesskaber, der via handlinger i praksis formår at initiere deres "små" fortællinger, deres offentlige forhandling af mening og håndtering af erfaringer og oplevelser på deres egne betingelser - og at formidle dem gennem praksis på "gadeniveau". Det er således ikke det enkelte sociokulturelle fællesskab, der er interessant; det ene kan for så vidt være lige så godt som det andet. Det, der er interessant er variationen af forskellige, folkelige konstellationer og mangfoldigheden af fortællinger, hvorigennem disse folkelige fællesskaber definerer sig selv og at nogle af disse havner i samfundsmæssige positioner, hvor de udgrænses og udgrænser sig selv og dermed havner på grænsen til det legitime. Det er tillig interessant at studere hvordan etikettering og artikulation har indflydelse på de forskellige fællesskaber og deres medlemmers muligheder. Pointen er, at de folkelige fællesskaber på forskellig vis er med til at løse de samme opgaver som de etablerede kulturtilbud for eksempel folkebibliotekerne - blot for en anden gruppe mennesker og gennem alternative virkemidler: at skabe identitet og identifikation på baggrund af alternative livsstile i mainstreamkulturen, muligheder for udvikling og eksperimenter med forskellige former for socialitet og kulturalitet og for at udøve nærdemokratisk indflydelse på fællesskabets værdi- og normgrundlag. De sociokulturelle miljøer kan betragtes som kuvøser for udviklingen af den resterende del af det menneskelige råmateriale, der er til stede i et hvert samfund. Derfor forlader jeg hermed termen "modkultur" og den polariserende, diktonomiske betragtemåde for i stedet fremover at anvende betegnelsen "sociokulturelle fællesskaber" og betragte disse fællesskaber som medkulturelle aktører i folkelige, kulturelle formationer.

\section{Noter}

1. - hvor det folkelige i nærværende kontekst betegner informelle, semi-strukturelle, valg- eller interessefællesskaber, der løbende opstår og udvikles som mindre, lokale fællesskaber. 
2. Center for Contemporary Culturel Studies ved Birmingham Universitet, Storbritannien

3. Pointen er at for det religiøse menneske, har metafysisk tænkning, så som troen på engle, mirakler, tungetale, etc. lige så stor praktisk betydning, som videnskaben har for det verdslige eller ideologi for det politiske menneske. Uanset hvilket livsfilosofisk grundlag den enkelte vælger at basere sit liv på, influerer det på vedkommendes muligheder for at forhandle mening offentligt, på vedkommendes håndtering af erfaringer og oplevelser og på den vidensorganisering, der er mulig. Og det til trods for at andre mennesker kan vælge at finde andre forklaringer, sociale, naturvidenskabelige, psykologiske, på selv samme fænomener og forholde sig herefter.

4. - på undersøgelsestidspunktet, hvilket vil sige efterår 2006 - sommer 2007.

5. En af konklusionerne på mine studier er, at ét formål med aktivisternes tilslutning til 1000fryd er at reducere samfundsmæssig kompleksitet. Ved at underlægge sig et kollektivs forholdsvist restriktive værdi- og normsæt, frigøres samtidig et enkelte menneske for den daglige genopfindelse af sig selv, som tilsyneladende er en af senmodernitetens konsekvenser. Denne kompleksitetsreduktion kan betragtes som både en reaktionær længsel efter tidligere tiders mere faste forhold eller et progressivt ønske hos visse mennesker (aktivisterne) om at tilhøre et fællesskab, hvor det er muligt og tilladeligt at engagere og forpligte sig selv.

6. DIY står for "Do It Yourself" og er et mantra fra den gamle punkbevægelse. Men faktisk bygger konceptet ifølge aktivisterne selv på inspiration fra hele gør-det-selv-bevægelsen i bred forstand.

\section{Referencer}

Agenda d. 28.4.2007 Hvorfor skal det vaere så svaert at vare imod? lokaliseret d. 14.6.2007 på WWW: http://www.dr.dk/P1/Agenda/Udsendelser/2007/ imod.htm

Allerslev Jensen, E (1985). Til bibliotekssagens fremme - trak af bibliotekstilsynets virksomhed frem til 1970. Edvard Petersens Biblioteksfond.
Ehn, B \& Lövgren, O (2001). Kulturanalyser. Gleerups Utbildning AB

Fjord Jensen, J (1988). Det dobbelte kulturbegreb - den dobbelte bevidsthed. I: H. Hauge og H. Horstbøll (red.) Kulturbegrebets kulturhistorie. Aarhus Universitetsforlag.

Geertz, C (u.å) Deep Play: Notes on the Balinese Cockfight. Lokaliseret d. 14.6.2007 på WWW: http:// webhome.idirect.com/ boweevil/BaliCockGeertz. html

Hastrup, K (2004). Det fleksible foellesskab. Århus Universitets Forlag.

Heath, J \& Potters, A (2006). Rebel - modkultur som globalt brand. Husets forlag.

Hussain, M, Yilmaz, F \& O'Conner, T (1997). Medierne, minoriteterne og majoriteten - en undersøgelse af nyhedsmedier og den folkelige diskurs I Danmark. Nævnet for etnisk ligestilling.

Kristiansen S \& Krogstrup HK (2002). Deltagende observation - introduktion til en forskningsmetodik. Hans Reitzels Forlag.

Korsgaard, O (1997). Kampen om lyset - 500 års undervisningshistorie. Gyldendal.

Lov om Biblioteksvirksomhed (2000) Biblioteksstyrelsen.

Manguel, A (2003). Af laesningens historie. Gyldendal.

Nørmark, D (2007). Modkultur findes ikke. Jyllandsposten 17. januar 2007.

Qvortrup, L (1996). Mellem kedsomhed og dannelse - variationer over et tema af Pico. Odense Universitetsforlag.

Rockwool fondens nyhedsbrev april 2006. Lokaliseret d. 14.6.2007 på WWW: http://www.rff.dk/filead$\mathrm{min} /$ dokumenter/Danske_nyhedsbreve/apr2006.pdf)

Scotson, J.L. \& Elias, Norbert (1994) The Established and the Outsiders: A Sociological Enquiry into Community Problems. 2. edition. Sage Publications. 
Sloterdijk. P (2002). Masse og foragt. Det lille forlag.

Staunæs, D (1996). Transitliv - andre perspektiver på unge flygtninge. Politisk Revy.
Swidler, A (1995). Cultural Power and Social Movements. In Johnston (et al.), Social Movements and Culture. Social Movements, Protest and Contension. Minnesota Press. 